\title{
An Engraved Bulbous-Necked Caddo Bottle from 410R33 at the mouth of the Sabine River, Orange County, Texas
}

Timothy K. Perttula

Follow this and additional works at: https://scholarworks.sfasu.edu/ita

Part of the American Material Culture Commons, Archaeological Anthropology Commons, Environmental Studies Commons, Other American Studies Commons, Other Arts and Humanities Commons, Other History of Art, Architecture, and Archaeology Commons, and the United States History Commons

Tell us how this article helped you.

This Article is brought to you for free and open access by the Center for Regional Heritage Research at SFA ScholarWorks. It has been accepted for inclusion in Index of Texas Archaeology: Open Access Gray Literature from the Lone Star State by an authorized editor of SFA ScholarWorks. For more information, please contact cdsscholarworks@sfasu.edu. 


\section{An Engraved Bulbous-Necked Caddo Bottle from 410R33 at the mouth of the Sabine River, Orange County, Texas}

\section{Creative Commons License}

(c) (1) (8)

This work is licensed under a Creative Commons Attribution-NonCommercial 4.0 International License 


\title{
An Engraved Bulbous-Necked Caddo Bottle from $410 \mathrm{O} 33$ at the mouth of the Sabine River, Orange County, Texas
}

\author{
Timothy K. Perttula
}

\section{Introduction}

41OR33 is a large prehistoric shell midden deposit in Orange County, Texas, about 8.5 miles southwest of the city of Orange, at the mouth of the Sabine River and just north of Sabine Lake in Southeast Texas (Figure 1). Before the site was destroyed for road fill in October 1956, limited archaeological investigations had been done there by avocational archaeologists and then by E. Mott Davis of The University of Texas at Austin (UT, Site files on record at the Texas Archeological Research Laboratory [TARL] at The University of Texas at Austin). During that work, a number of Native American burials were exposed and excavated, including one burial with an engraved bulbous-necked ancestral Caddo ceramic bottle. The bottle was donated by Edgar W. Brown, Jr. to UT in October 1956. I recently documented this vessel, which is a far-flung companion to bulbous-necked and spool-necked Caddo bottles from post-A.D. 1600 sites in the Red River and Ouachita River basins in East Texas and Southwest Arkansas (Ann M. Early, December 2018 personal communication) as well as several post-A.D. 1600 sites in East Texas such as the Taylor site (41HS3) in the Big Cypress Creek basin (see Suhm and Jelks 1962:Plate 37 a, c-d, g, 1, n, Plate 38:i-j, m-m', and o, Plate 44a-e, g, i, m, and Plate 76b-c, i, 1; Perttula et al. 2010:Figures 5, 7-11, 14a-c, 15a-c, 16a, 17c).

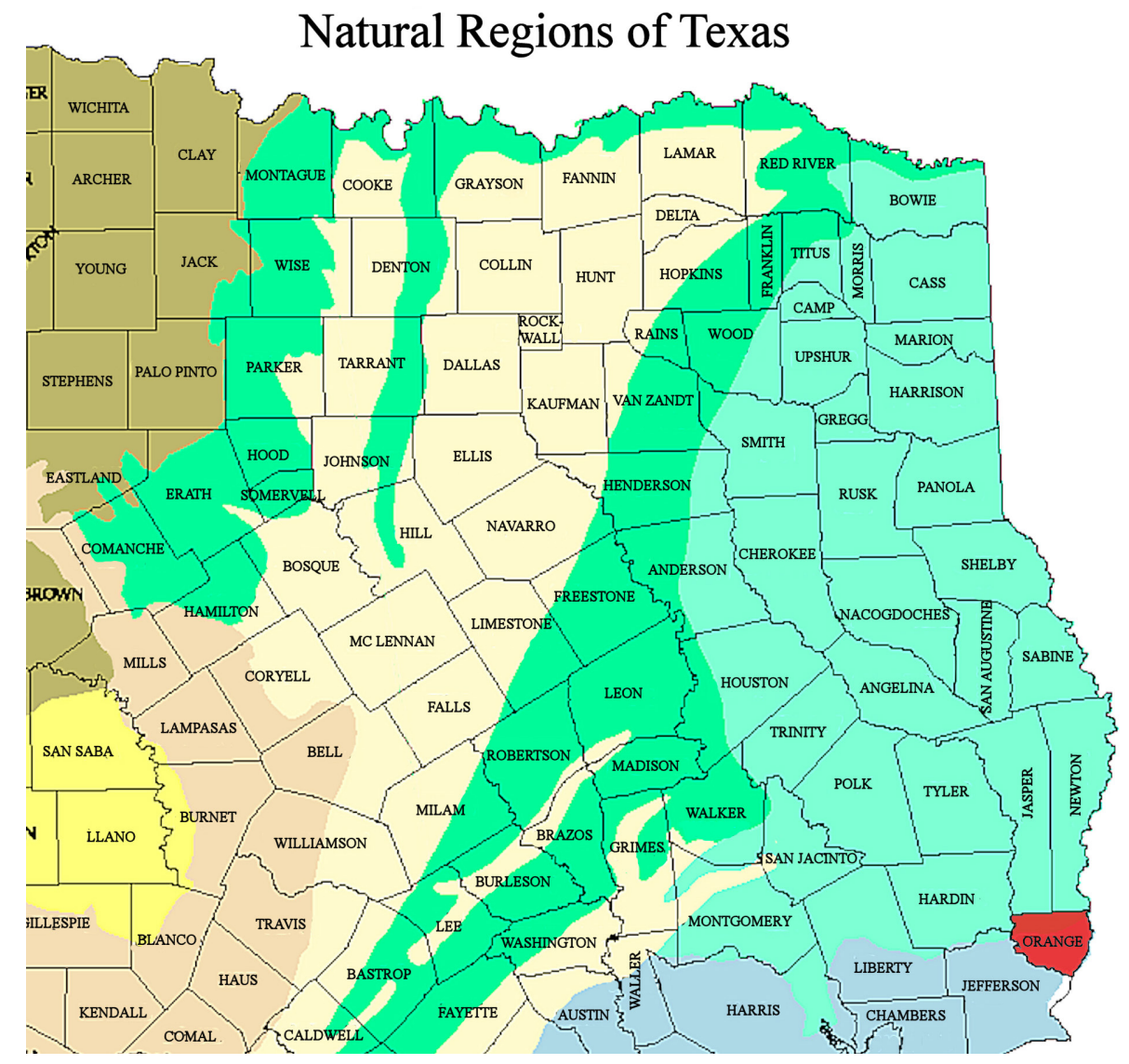

Figure 1. The location of Orange County in Southeast Texas. 


\section{Vessel Documentation}

SITE NAME OR SITE NUMBER: 41OR33

VESSEL NO.: 1, E. W. Brown Collection, Shell Midden burial

VESSEL FORM: Bottle with a bulbous neck (Figure 2a)

NON-PLASTICS AND PASTE: grog

RIM AND LIP FORM: Direct rim and a rounded lip, with a distinct bulbous area in the middle to lower portion of the bottle neck (Figure 2a)

CORE COLOR: B (fired and cooled in a reducing or low oxygen environment)

INTERIOR SURFACE COLOR: dark grayish-brown

EXTERIOR SURFACE COLOR: dark grayish-brown; fire clouds on the bottle neck and body

WALL THICKNESS (IN MM): neck, $3.9 \mathrm{~mm}$

INTERIOR SURFACE TREATMENT: none

EXTERIOR SURFACE TREATMENT: smoothed

HEIGHT (IN CM): 9.3

ORIFICE DIAMETER (IN CM): 2.6

DIAMETER AT BOTTOM OF RIM OR NECK (IN CM): 3.3 $\mathrm{cm}$; maximum body diameter: $6.5 \mathrm{~cm}$

BASE DIAMETER (IN CM) AND SHAPE OF BASE: $3.7 \mathrm{~cm}$, circular and flat

ESTIMATED VOLUME (IN LITERS): 0.15

\section{DECORATION (INCLUDING MOTIF AND ELEMENTS}

WHEN APPARENT): The engraved elements on the vessel body include two horizontal engraved lines at the top of the body and a single horizontal engraved line near the bottom of the vessel body (Figure 2b). Between these lines are three sets of vertical and curvilinear scrolls and scroll lines that are divided by sets of two or three vertical engraved lines that divide the sets of scrolls. One of these sets of vertical engraved lines contains a zone of vertical and horizontal cross-hatched lines (Figure 2b).

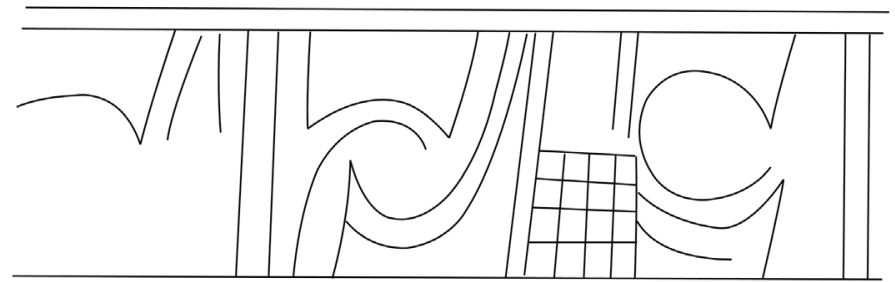

Figure 2. Bulbous-necked engraved bottle from 41OR33: a, photograph; $b$, decorative elements. 
The recovery of an engraved Caddo ceramic bulbous-necked bottle with decorated elements that compare favorably to the Taylor Engraved type in a burial at 41OR33 in Southeast Texas is testimony to the spatially extensive contacts (at least 190 miles from the site to the vessel's likely place of manufacture in East Texas) after ca. A.D. 1600 between ancestral Caddo peoples living in East Texas, or less likely Southwest Arkansas, and the aboriginal occupants of Southeast Texas. These peoples were likely affiliated with the Atakapan-speaking Akokisa or Orcoquisac tribes (see Aten 1983; Ricklis 2004).

\section{Acknowledgments}

Thanks to Marybeth Tomka for access to the ceramic vessel collections at TARL. Thanks to Ann M. Early for her comments on the age and distribution of bulbous- and spool-necked bottles in the Caddo Area. Lance Trask prepared Figures 1 and $2 \mathrm{~b}$ in this article.

\section{References Cited}

Aten, L. E.

1983 Indians of the Upper Texas Coast. Academic Press, New York.

Perttula, T. K., B. Nelson, R. L. Cast, and B. Gonzalez

2010 The Clements Site (41CS25): A Late 17th to Early 18th-Century Nasoni Caddo Settlement and Cemetery. Anthropological Papers No. 92. American Museum of Natural History, New York.

Ricklis, R. A.

2004 The Archeology of the Native American Occupation of Southeast Texas. In The Prehistory of Texas, edited by T. K. Perttula, pp. 181-202. Texas A\&M University Press, College Station.

Suhm, D. A. and E. B. Jelks (editors)

1962 Handbook of Texas Archeology: Type Descriptions. Special Publication No. 1, Texas Archeological Society, and Bulletin No. 4, Texas Memorial Museum, Austin. 